\title{
Building an annual series of English wheat production in an intriguing era (1645-1761): methodology, challenges and results
}

\author{
José L. Martínez-González, Gabriel Jover-Avellà \& Enric Tello
}

KEYWORDS: wheat production, England, Davenant's Law, agricultural revolution.

JEL CODES: N50, N53, Q11, Q54.

his article presents a method for estimating an annual series of English
wheat production in physical units during the intriguing period of 1645-1761,
when the English Agricultural Revolution began. It is based on Davenant's Law and the assumption of a decrease in long-term crop variability, taking into account the yields obtained from probate inventories and farm accounts. The exercise confirms the idea that the King-Davenant accounting of the inverse variation of prices and quantities through price elasticity was indeed a common rule at that time, whereas income elasticity did not become a decisive factor until the mid-18 ${ }^{\text {th }}$ century. From then on it gained momentum, as can be observed by lengthening the series until 1884. The new series of English wheat production presented here also shows that, from a physical and environmental perspective, the Agricultural Revolution began before 1750 and resumed after 1800. The results are consistent with recent estimates of agricultural GDP put forward in the literature on English economic history. 


\section{Construyendo una serie anual de producción de trigo inglesa en una etapa fascinante (1645-1761): metodología, desafíos y resultados}

\section{PALABRAS CLAVE: producción de trigo, Inglaterra, ley de Davenant, revolución agraria.}

\section{CÓDIGOS JEL: N50, N53, Q11, Q54.}

$E$ ste artículo presenta un método para estimar una serie inglesa de producción de trigo en unidades físicas durante el periodo 1645-1761, cuando empezó la revolución agrícola. Este método se basa en el supuesto de un descenso a largo plazo de la variabilidad de las cosechas, teniendo en cuenta los rendimientos agrícolas estimados por diversos autores a partir de los inventarios testamentarios y las contabilidades agrarias. El ejercicio confirma la idea de que la ley de King-Davenant fue una regla común en la época, y la elasticidad renta no fue un factor decisivo hasta mediados del siglo XVIII, cuando empezó a ganar impulso, como se puede observar alargando la serie hasta 1884. La nueva serie inglesa de producción de trigo presentada aqui también muestra que, desde una perspectiva física y ambiental, la revolución agrícola fue un fenómeno que comenzó antes de 1750 y se reanudó después de 1800. Los resultados encontrados son consistentes con las recientes estimaciones del PIB agrícola presentadas por la historiografía económica.

Received: 2017-07-05 - Revised: 2018-06-19 - Accepted: 2018-09-11

José L. Martínez-González [orcid.org/0000-0003-4157-0125] is part-time Lecturer Professor at Tecnocampus-Universidad Pompeu Fabra and at Universitat Oberta de Catalunya. Doctoral Researcher at Universitat de Barcelona. Address: Department d'Història Econòmica, Institucions, Política i Economia Mundial, Av. Diagonal, 690, 08034 Barcelona (Spain).E-mail:jlmartinez.economic.history@gmail.com

Gabriel Jover-Avellà [orcid.org/0000-0002-6430-2329] is Associated Professor of Economic History. Address: Departament d'Economia, Universitat de Girona, Montilivi Campus, 17003 Girona (Spain). E-mail: gabriel.jover@udg.edu

Enric Tello [orcid.org/0000-0002-4970-1524] is Professor of Economic History. Address: Department d'Història Econòmica, Institucions, Política i Economia Mundial, Av. Diagonal, 690, 08034 Barcelona (Spain).E-mail:tello@ub.edu 


\section{INTRODUCTION}

One of the most widely discussed aspects regarding the English Agricultural Revolution has been quantifying the magnitude of the agricultural product and GDP per capita. The Agrarian Reform (1536) and Social Revolutions (1640 and 1688) disrupted one of the most useful sources used as a proxy for crop production in continental Europe in precapitalist times: tithes (Kain \& Prince, 2006). This lack of data has led to estimations being made from indirect methods and other sources. From a demand-side approach, agricultural production has been calculated on the basis of consumption per head, population, prices and elasticities. From a supply-side approach, on the other hand, the sources have been a growing set of non-randomly selected site-specific probate inventories and farm accounts. This methodological diversity has produced widely varying estimates due to the differing temporal and spatial features and sources used in each case. For instance, Morgan Kelly and Cormac Ó Gráda (2013) have called for an upward adjustment of the recent agricultural production estimated by Stephen Broadberry, Alexander Klein, Mark Overton and Bas van Leeuwen (2015). There is also an ongoing debate over the dating of the English Agricultural Revolution, raised by Mark Overton (1996a) and Robert C. Allen $(1991,2008,2009)$. Another open question is whether waves in agricultural output and productivity might have been responsible for the slow progress of English economic growth between 1760 and 1815, and for its later acceleration. To help determine the answers to these questions, Robert Allen has called for new methods to be developed that allow a better inference of changes in production and yields (Allen, 1999: 209-211).

In partial response to Allen's request, the aim of this paper is to estimate an annual series of wheat output in England between 1645 and 1761. A new method is presented based on Davenant's Law (1699). Charles Davenant was a contemporary author from that intriguing period and the first to propose estimating the inverse variations of wheat harvests from the variations of their prices. He did this using data previously collected by Gregory King. The usefulness and accuracy of this method has been highlighted by historians such as Edward Anthony Wrigley (1987) and economists such as Anthony M. Endres (1987) and Jean-Pascal Simonin (1996). The method is also currently being used to estimate production from prices when facing unreliable statistical output data (Nielsen, Smith \& Guillén, 2012). We will use it for the same purpose, adding other assumptions, i.e. to estimate a final aggregate gross and net production of wheat -meaning gross output minus seeds, animal feeding and losses-from a demand-side approach, to then compare the outcome with the supply data assembled by other historians who have considered yields, population growth and long-term income growth. 
Notwithstanding the importance of wheat it is worth stressing other grains, such as barley, rye and oats, as well as pulses, turnips and clover, potatoes and livestock. However, as Robert Allen stated, during the transition from subsistence to market agriculture and urban development wheat dominates the history of crop yields, and the history of wheat shows the importance of the pre-1750 agricultural revolution (Allen, 1999: 225).

This paper is structured as follows. The first section summarizes the current debates in agricultural historiography. The second explains the methodology used to build the new series. The third assesses the results obtained comparing them with current estimates, and justifies their accuracy. And the fourth concludes.

\section{THE PROBLEM WITH ASSESSING THE ECONOMIC PERFORMANCE OF ENGLISH AGRICULTURE PRIORTO 1884}

There are no statistical data on the annual physical wheat production in Britain prior to 1884 (Mitchell, 1988). Neither can we count on any proxy such as tithes, traditionally used as sources in continental Europe. Thus, over the last thirty years economic and agricultural historians have had to use other indicators to assess the performance of English agriculture: total physical output, yields, agricultural production, consumption and elasticities. As can be seen in Table 1, physical output estimates are scarce and never annual. One of the earliest was contributed by Phyllis Deane and W. A. Cole (1967:62-8) and showed a rise in wheat production during the $18^{\text {th }}$ century from 29 to 50 million bushels $(73 \%)$, substantially larger than the growth in other grains (43\%). Gross production can be calculated using the acreage estimates and Allen's yields $(2005: 28,32)$ put forward for the period 1300 to 1850 , and this highlights a dramatic increase in production between 1800 and 1850 .

Based on some assumptions regarding the consumption of bread and flour by labourers, Robert Allen also presented an estimate to support his idea that the volume of wheat demand was bigger than that put forward by Gregory Clark (2007), according to which wheat demand would have gradually risen from 40 million bushels in 1770 to 170 or more in 1850, with a rapid increase from 1820 onwards. Allen multiplies the share of bread and flour in the average wages by the employed population (manual labour). He obtains the total income spent on bread and flour, which he divides by their respective prices, deducting their volume. Applying a 2:1 relationship between bread and flour, he calculates the total wheat demanded in bushels. To do this, he supposes an income elasticity of bread and flour demand equal to zero at the upper average income levels of manual labourers. The latest estimates have been presented in Broadberry et al. (2015), with decennial av- 
erages of net physical output and cultivated area taken from a Manorial Accounts Database, a Probate Inventories Database and a Modern Farm Accounts Database following a supply-side approach. All of these estimates are summarized in Table 1.

\section{TABLE 1}

Physical output and demand of wheat in millions of bushels, according to different authors, 1650-1884

\begin{tabular}{lccc}
\hline Years & Estimate & Type of estimate & Author \\
\hline $1650-59$ & 27.01 & Net output & Broadberry et al. (2015) \\
$1700-09$ & 27.94 & Net output & Broadberry et al. (2015) \\
1700 & 30.00 & Gross output & Deane and Cole (1967) \\
1700 & 26.60 & Gross output & Allen (2005) \\
$1750-59$ & 31.48 & Net output & Broadberry et al. (2015) \\
1750 & 42.00 & Gross output & Allen (2005) \\
1770 & 40.00 & Demand & Allen (2007) \\
$1800-09$ & 46.32 & Net output & Broadberry et al. (2015) \\
1800 & 50.00 & Gross output & Deane and Cole (1967) \\
1800 & 50.00 & Demand & Allen (2005) \\
$1850-59$ & 73.69 & Net output & Broadberry et al. (2015) \\
1850 & 100.80 & Gross output & Allen (2005) \\
1850 & 170.00 & Demand & Allen (2007) \\
$1860-69$ & 86.07 & Net output & Broadberry et al.(2015) \\
1884 & 80.20 & Gross output & British Statistics (1988) \\
\hline
\end{tabular}

Source: our own calculation. Calculation from the references given in the table.

A second and much more frequent approach is that related to land productivity (yields), measured in bushels per acre. Although we can find abundant information on the Middle Ages, and again in the $19^{\text {th }}$ century, estimates on the early modern era are scarce. This has led researchers to use intermediate methods, with estimates being elaborated from sitespecific primary sources, mainly local probate inventories (Overton, 1979, 1991, 1996a, 1996b; Allen, 1988, 1989, 1991, 1999; Glennie, 1991; Turner, 1982, 1986; Theobald, 2002; Yelling, 1970, 1973) and farm accounts (Turner, Becket \& Afton, 2001). For the second half of the $18^{\text {th }}$ century and the beginning of the $19^{\text {th }}$ century, there is the wellknown work by ArthurYoung (see John, 1986). There are also some public statistics, such as the Harvest Inquiries of 1794, 1795 and 1800, Crop Returns in 1801 (Turner, 1982), and the Board of Agriculture Surveys in 1816 (see John, 1986). The works of James Caird in 1852, Mark Lane Express in 1860 and 1861 (John, 1986), or those by John B. Lawes and Joseph H. Gilbert (1893) regarding the results of the Rothampsted experiments between 1852 and 1884. A summary of all these contributions can be found in a chapter 
on the wheat question published by Turner, Beckett and Afton (2001: 116-49). The figures proposed by M. J. R. Healy and Eric L. Jones (1962) are also available, based on market studies of Liverpool grain merchants, and from data published by B. A. Holderness (1989), which reported $16 \mathrm{Net}$ bu/acre in 1750, 19.5 in 1800, 20.5 in 1810, and 26 in 1850.

Liam Brunt $(2004,2015)$ used another different approach from the supply-side perspective. This author analysed the production of wheat and its yields. To control for variability, he used climatic variables (temperatures and rainfall), which he related to output data registered by the cereal traders of Liverpool between 1815 and 1859 by means of a regression model (Healy \& Jones, 1962). He then predicted crop movements backwards before introducing technological variables to establish the trend.

All of these data have created a difficult puzzle to fit together. Some basic facts do seem quite clear, however. Agricultural output per head increased between 1700 and 1760 (Crafts, 1980).Yet, there is a long debate on what happened before 1700 and after 1760 . Mark Overton (1996a) argued that it was between 1750 and 1850 that the Agricultural Revolution took place, whereas Allen pointed out that output grew slowly, and yields fell during the second half of the $18^{\text {th }}$ century. The first wave of innovations (clover, turnips, new Leicester sheep, convertible husbandry) did not seem to contribute much to economic growth from 1760 onwards, and Nicholas Crafts even talked about a Malthusian shadow threatening England at the end of the $18^{\text {th }}$ century (Crafts, 1980). It was not until the first half of the $19^{\text {th }}$ century that agricultural output started to rise significantly. Assuming this would help to explain the slow advance of the first stage of the Industrial Revolution and the faster next stage. Allen also suggested a three-stage general chronology: from 1520 to 1739, from 1740 to 1800 , and from 1800 onwards. During the first stage, there would have been significant agricultural growth, also pointed out by Jones (1965) and Kerridge (1967) and other authors. During the second stage, output only increased $10 \%$ (and yields also began to decline), whereas from 1800 to 1850 , agricultural production grew by 65\% (Allen, 1999: 210-25).

According to Gregory Clark (2002: 16-25), population growth during the Industrial Revolution was largely supported by food imports. Rather than a productive revolution, there would have been a reorientation of agriculture towards human feeding. Before 1869, improvements in land yields would have been much more relevant than in labour productivity. In this author's opinion, it was a long period of modest but constant advance in crop yields (1600-1750). After that period, a 50-year pause would have followed, when both yields and labour productivity decreased. And then, after 1800, land and labour productivities would start to grow slowly but steadily. 
Finally, under another perspective related to consumption, food demand and elasticities, E. J. T. Collins (1975) claimed that it was not until at least 1745 that the increase of income made wheat the most consumed cereal by the English population. During the $17^{\text {th }}$ and $18^{\text {th }}$ centuries rye bread, and that made by mixing other cereals, were basic foods. Maslin (wheat and rye bread) and muncorn (barley and oat bread) predominated in the Lowlands. Barley, rye, oat, beans and pulses marked the prevailing consumption pattern. High substitution elasticity would explain why England avoided famine (Appleby, 1979; Hoyle, 2013). Even during the Tudor period, and that of the first Stuarts, Malthusian pressure reduced wheat consumption. Something similar was claimed by chroniclers of the time. Gregory King described wheat consumption as being in the minority at the end of the $17^{\text {th }}$ century. According to Tooke and Newmarch (1838), the increase of wheat bread consumption was slow. In south-west England, the working classes (including agricultural labourers and small farmers) consumed barley. In 1795 less than $45 \%$ ate wheat bread, while barley still prevailed in the peninsular counties (55\%). In Wales, staple food consisted of barley and oats, whereas in the Midlands the consumption pattern was more diversified (Collins, 1975: 98-9).

Christian Petersen (1995) dated the beginning of the golden age of wheat bread between 1770 and 1870, not earlier. We know that between 1656 and 1704 wheat became more expensive than rye (its relative price increasing from 1.23 to 1.89 ). Although wheat prices decreased later, it was still more expensive than rye in 1739 (1.43), and from 1750 onwards its exchange rate worsened again according to our own calculation using Gregory Clark's prices (2004, 2005, 2007). Using the output estimates of Broadberry et al. (2015: 98, 112), we find that in 1650 wheat would have constituted $38.4 \%$ of grains (27.01 million of bushels on average), and $36.7 \%$ in 1750 (31.48 million bushels on average).

Another sign of increased wheat demand is international trade. It was not until the 1760s that Great Britain became a wheat importer (Ormrod, 1985). Government policies must also have had an influence on this fact: several regulations (Assize of Wheat, Bounty Acts) kept wheat prices high thereby affecting domestic consumption (even though it was decreasing in the long run), a fact harshly criticized by Adam Smith in his Wealth of Nations (1776). From the second half of the $17^{\text {th }}$ century, export subsidies began to be applied, such as those implemented in 1663 and 1689, although they do seem to have been more effective in the first half of the $18^{\text {th }}$ century. They were cancelled in periods of scarcity, as in the late nineties of the $17^{\text {th }}$ century (Comber, 1808; Hipkin, 2012). Some econometric studies also confirm the influence of Corn Bounties on wheat supply (Tello et al., 2017). At the same time, however, it seems that wheat was the most integrated cereal in the different English counties as early as the 1690s (Chartres, 1985, 1995) -although this remains a controversial issue. 
In summary, it would seem that cereal consumption was diverse in Britain during the $18^{\text {th }}$ century and wheat did not start to stand out until at least after 1760 . Consequently, it is acceptable to assume that the slow income per head rise was not initially a significant factor in wheat demand. Whereas farm management in relation to soil fertility, land yields and labour productivity, together with weather impacts and expectations, determined the evolution of supply, population growth was the main driver of wheat demand. This fact suggests an inverted U-shaped wheat income elasticity $\left(\varepsilon_{i}\right)$ over time. In a first phase, it would be null or very low. As wheat bread -and other wheat products- increasingly started to be consumed and replaced other types of bread to become a basic product, $\varepsilon_{i}$ increased. It only fell again when the standards of living improved, consumption diversified, people's preferences changed, and basic needs were better met at the end of the $19^{\text {th }}$ century. We know that elasticities are not fixed over time. As recent research shows, while $\varepsilon_{i}$ is currently low in both countries where wheat is secondary and well-developed countries, it is high in under-developed ones (Abler, 2010).

It has also been observed that price elasticity tends to fall when income elasticity does (Abler, 2010: 21). This trend has been confirmed by Campbell and Ó Gráda's work (2011), which showed that the price elasticity of wheat demand fell in the very long term. These authors analysed Robert Fogel's (2004) and Gunnar Persson's (1999) divergent positions on the issue. Fogel assumed a low price elasticity of demand throughout the Modern Age in England (-0.183). He also provided complementary reasons for product variation such as income distributed unequally and government passivity (Campbell \& O’Grada, 2011: 875). Conversely, Gunnar Persson (1999) and Rafael Barquín (2005) proposed higher elasticities (-0.6 and $-0.6 /-0.8$, respectively). This meant a significantly greater threat of famine, mortality outbreaks and dearth compared to Fogel's assumption. In light of these two positions, Campbell and Ó Gráda (2011) adopted a more dynamic vision: if the price elasticity of English grains fell between half and one third in the long term, harvest variability would have substantially decreased, leading to a new period of economic, political and biological progress.

Indeed, most of these pieces of research on agricultural price elasticities may be right in their own terms. The problem lies in the different sources and methods applied to different historical times, which makes it difficult to reach conclusive results. A great deal of these studies have been carried out on food products as a general category rather than wheat. It can be assumed that the absolute value of wheat income elasticity $\left(\varepsilon_{i}\right)$ was much lower than that of other food items, such as meat. Nicholas F. R. Crafts (1980) quotes three old works that use cross-sectional data. The first, published by D. Davies (1795) estimated a food $\varepsilon_{i}$ near to 1 . The second, by F. M. Eden (1797), obtained similar income elasticity for a group of poor agricultural labourers. And the third, conducted by W. Neild 
(1841) for industrial workers in Lancashire between 1836 and 1841, established an $\varepsilon_{i}$ of 0.853. Crafts ends up calculating an $\varepsilon_{i}$ of 0.74 for the period from 1820 to 1840 , and applying a similar value (0.7) to the period $1700-60$ for food in general, though not for wheat (Crafts, 1980: 162). Clark (2002: 29) used similar values in his agricultural demand equation, with an $\varepsilon_{i}$ of 0.6. In Clark, Cummings and Smith (2010), a value of 0.6 is still found for 1860 . However, Clark considered the increase in income per head to be small between 1760-69 and 1860-69. Therefore, once more it is assumed that the role played by income elasticity of food demand would have been limited. Following Crafts and Clark, Allen (1999: 213) also suggested a food price elasticity of 0.6.

According to Robert Allen, Clark assumed income elasticity to be below 0.6 because his budget studies did not include high incomes. For the same reason, Crafts estimated an income elasticity for all food products rated at 0.5 . That meant a small crossed elasticity of 0.1 , and a price elasticity of -0.6 . Some years later, Allen (2005) dealt with this subject again, obtaining an income elasticity of 0.5 in 1300, of 1 in 1500 and of 0.5 after 1500. Later, in 2007, he estimated wheat output from consumption per head by assuming demand income elasticity for bread and flour of 0 at those levels above the average income. On the other hand, applying Craft's food $\varepsilon_{i}$ for wheat (0.5), Barquín (2005: 244-50) concluded that wheat price elasticity in England must have ranged between -0.6 and -0.8, questioning Fogel (-0.18) and King-Davenant's Law (-0.4), and agreeing with Parenti (1942) and Persson (1999). By way of conclusion, studies conducted on food price elasticity $\varepsilon_{p}$ range from -0.18 to -0.80 , and lately $-0.6<\varepsilon_{p}<-0.8$. For income elasticity $\varepsilon_{i}$, the range is between 0 and 1 , and more precisely between 0.5 and 0.7. Campbell and Ó Gráda estimates with the available data provided by Turner, Becket and Afton (1997) would be a demand price elasticity of -0.73 (using net yields) in the period 1268-1480, or of $-0.57 /-0.55$ (using gross yields), that would have been lowered to some $-0.23 /-0.35$ from 1750 to 1850 (using gross wheat yields).

\section{METHODOLOGY USED TO ESTIMATE A YEARLY SERIES OF PHYSICAL WHEAT PRODUCTION IN ENGLAND (1640-1761)}

If we wish to obtain an annual series of physical wheat output on the basis of probate inventories, there is little we can do. Doing the same thing based on consumption (like Clark or Allen), the results are so general that they do not allow much advance either. But by integrating the two approaches, the outcome is better than the sum of the parts. This is the holistic principle supported in this article following Allen's advice: since all methods are indirect (even the one created by Mark Overton relying on probate inventories), it is inevitable that we start from one or several theoretical assumptions. This means that his- 
torians must examine all these approaches without underestimating any position, testing all of them all equally against the scarce empirical evidence available (Allen, 1999:211).

Accordingly, we propose the following estimation method. First, deduce the yearly variation of harvests from the variation of prices. To do this, we need a mathematical expression that relates prices and quantities. Taking the price and physical quantity for the year 1700 (a year of average production), and knowing the prices of other years, we can calculate the physical quantities of all years of the period with an equation based on a price elasticity assumption. We do not have any prior econometric equation for the period 1640-1761. For a standard regression model, we need the two variables of price and quantity, but we do not have the latter. We do, however, have the King-Davenant-JevonsBouniatian equation (Davenant, 1771[1699]; Endres, 1987; Wrigley, 1987; Simonin, 1996). This expression was developed from observations made in the $17^{\text {th }}$ century. There is no written proof that it was developed as such by Gregory King. For this reason, it is believed that it was some kind of "law" discovered by Charles Davenant, who was the first to quote it. According to this "law", the progressive reductions of one tenth of production generated successive price rises in the sequence of 1.3, 1.8, 2.6, 3.8, and 5.5. Compared to a normal harvest, one at $90 \%$ would increase the equilibrium price of wheat $130 \%$. A harvest at $80 \%$ would increase the price $180 \%$. This supposed "law" -or rather, empirical regularity corresponding to a given historical context- was formalized by Stanley Jevons through an algebraic expression, and later improved by Mentor Bouniatian as follows:

$$
y=0.757 /(x-0.13)^{2}
$$

Calculated by means of Davenant's Law, price elasticity is -0.403 , although Barquín (2005: 244-50) corrected this value downward to 0.360. Generally speaking, Davenant's Law has been acknowledged by economic historians for a long time, from Tooke and Newmarch (1838) to Thorold Rogers (1877) and Bernard H. Slicher van Bath (1963). For example, Mentor Bouniatian proved its validity for American corn price elasticity between 1866-91, and Prussian rye around the middle of the $19^{\text {th }}$ century. Anthony Wrigley accepted its prestige, although it was not clear for him whether Davenant talked about net or gross product, or whether it was also applicable to other places and times (Wrigley, 1987; Nielsen, Smit \& Guillén, 2012). There are other authors who have disregarded the price elasticity resulting from Davenant's Law, either considering it to be too low or merely a speculative generalization with no real basis (Barquín, 2005; Persson, 1999; Parenti, 1942). However, Campbell and Ó Gráda's (2011) research on English wheat harvest variability suggests a decrease in price elasticity in the very long term from a value of -0.57 for $1268-1480$ to -0.23 for $1750-1850$. Surprisingly, Davenant's value is an average of both 
values that can only be applied to an intermediate stage. Another recent study on $19^{\text {th }}$ century Saxony confirms the validity of this (Uebele, Grünebaum \& Kopsidis, 2013).

Furthermore, it seems that this "law" also formed part of English traders' practical knowledge. According to William Petty, a good trader had to possess certain abilities: he had to be good at arithmetic and accounting, intelligent, a connoisseur of trading practices and the weights used at every commercial site, and of all the currencies, interest rates and exchange rates. He needed to know about the seasons in which agricultural raw materials were sowed in different places, the shipping points and routes, the relationship between volumes and transaction prices, transport costs, customs duties and wages (1927: 192). Charles Davenant (1656-1714) was himself one of these well informed English traders and extremely knowledgeable about all such $17^{\text {th }}$-century practices and rules. Taking advantage of his privileged high-ranking position, he published in 1699 An Essay upon the Probable Methods of Making a People Gainers in the Balance of Trade (Davenant, 1771 [1699]). Interestingly, this is a work about policy to be applied to fight the fluctuation of harvests, about the prices of grain, and how to profit from trade. Davenant calculated that in a period of good harvests, England could count on five months of grain stock. By estimating the price rise resulting from bad harvests and the observation of Dutch barns management, he suggested that England should take similar stock measures to avoid famine for the poor (Hutchison, 1988: 51-2).

We therefore assume the implicit price elasticity of Davenant's "law" to have been a knowledgeable observation of the time, a very good historical source in itself. The method deriving from this assumption is as follows. In equation (1), $y$ is an index number of the wheat price. Assuming that Clark's price of 1700 is equals to $1(y=1)$, we calculate the values for the other years: $x$ represents the proportion (or quotient) between the actual quantity (the numerator) and the "usual" average quantity (the denominator). We assume that this quotient is equal to 1 for 1700 , that is, the numerator and the denominator are the same (real quantity = usual quantity), which means considering this an average harvest of a "usual" year according to Broadberry et al. (2015) and Deane and Cole (1967) (see also Table 8 below). Then, for the other years the numerator (the real quantity of the market) is the unknown variable whose value is to be determined.

It should be noted that in this way we obtain a series in millions of bushels according to the implicit price elasticity of Davenant's Law, but without revealing a trend. We have inferred variations of quantities from variations of prices without considering that both demand (the population to be fed) and supply (wheat acreage and produce) also changed. Ignoring this would mean assuming a completely unrealistic stationary state where only harvests and prices changed yearly. Therefore, we have incorporated a population index 
to obtain a second series, which registers short-term movements (based on King-Davenant's Law) plus the trend derived from population change. The following step is to add another trend factor, income variation, together with an average factor $(n)$ greater than 0 , which attenuates the effect of income on wheat demand (e.g. 0.4), providing us with a third series. The final output in the second and third series depends on the figure that we take as "usual" in 1700 (the denominator). If the output is net, the calculated series is for net production. If the output is gross, the calculated series is for gross production.

Finally, we estimate market demand. If the series obtained shows a net output, we have the supply of domestic produced wheat. If we deduct the net foreign balance (the difference between imports and exports), we obtain the demand for wheat. If the series obtained is for gross output, the part devoted to seeds and other uses must be deducted from the resulting series and the foreign balance added (everything depending on the starting value as the "usual" average quantity).

By means of this method we obtain four output series: in the first one (series I), we take the physical net output provided by Broadberry et al. (2015:398) to be the "usual" quantity in 1700 and we add demographic pressure using the estimates provided by Wrigley. Series II incorporates income growth accumulated in the long term, calculated using the real GDP index taken from Broadberry et al. (2015) and corrected with a factor of 0.4. For series III, we take the value provided by Deane and Cole in 1700 (1967) as an alternative "usual" quantity. Unlike the former series, this value is of gross output and we apply the same former population index to it. As a result, it also shows a gross series of wheat production. The fourth series (IV) is obtained by including the same income growth as in series III. To infer total demand in the English market, when necessary, we add the net foreign balance to the net series of each of the series (Mitchell, 1988; Ormrod, 1985).

The aim of estimating four series is to verify two issues. Firstly, whether using net data or gross data is more accurate as a starting point. Secondly, to consider whether it is better to add only population growth as a trend factor, or to add national income as well. We use a physical datum of 1700 as the starting point because it was a regular or "usual" average year. The annual average income from the real GDP is one of the few we have and, according to Broadberry et al. (2015), it was obtained independently from the other values (Clark's prices, and Wrigley's population estimated from parish records). We must be aware that GDP and population are statistically related. The series of GDP and wheat prices must also be correlated, given that agricultural GDP forms part of total GDP, and wheat was in turn an important component of agricultural output. Otherwise we would suspect that the series are not derived correctly. Upon performing the independence test, 
all of the above applies, a correlation coefficient of -0.36 between wheat prices and real GDP, of 0.58 between population and real GDP, and -0.0428 between wheat prices and population, with a critical value at $5 \%$ to two tails equal to 0.20 for $n=91(1650-1740)$.

The second part of the method used compares the four series obtained, to the available database of land yields, labour productivities and prices at a site-specific micro-level (probate inventories and farm accounts), as well as with other output estimations and total demand accounts at a macro-level. For the net series I and II we carried out an estimation of the gross yield per acre, dividing these series by the surface area of land cultivated with wheat -2 million acres if we follow Broadberry et al. (2015) for 1650, 1700, 1750 or Allen for 1750 - and adding $2.5 \mathrm{bu} /$ acre as the part devoted to seeds and other uses. For the gross series III and IV, the yield is calculated directly by dividing them by 2 million acres. Following that, we compared the average yields per acre for series I, II, III and IV to those taken from probate inventories and farm accounts. We analysed the deviations to determine which series is closer to current site-specific knowledge. We then performed the opposite procedure to determine what the average surface area should be in order for each of the series to better fit the available yield database we have.

Next, we compared the four series with all of the output estimates available, both net and gross, and with demand figures to again observe which has a lower deviation. Finally, we applied a Cobb-Douglas regression model to the period 1640 to 1761 for the four logarithmical demand series through the non-linear equation $D_{\text {wheat }}=P_{\text {wheat }}^{\alpha} I^{\beta}$, where $D_{\text {wheat }}$ stands for the national annual wheat demand in bushels, $P_{\text {wheat }}^{\alpha}$ stands for annual wheat prices, $I$ is the annual English GDP as a measure of national income (Broadberry et al., 2015), $\propto$ stands for an approximation of price elasticity, and $\beta$ represents income elasticity. In addition, we also calculated the price elasticity of each of the four series by means of the method proposed by Campbell and Ó Gráda (2011), that is, by differentiating the price and quantity series to eliminate the trend and developing a simple regression model.

Accordingly, we chose the series with least deviation and tested whether the short-term movements were coherent. To do this, we examined the historiography and verified its correspondence with the movements of the series. Additionally, we linked the chosen series with the first statistics available from 1884 onwards by gradually incorporating a growing income-effect from 1761 onwards (obtaining a new series of net national production, series $\mathrm{V}$ ) and then adding the net external balance (obtaining a new demand series, series VI). The aim of making this connection was to verify whether the series fits the current long-term historiographical perspective, acknowledging that the price elasticity implicit in Davenant's Law put forward in 1699 gradually lost accuracy and relevance with 
economic growth in the long run. As Campbell and Ó Gráda (2011) demonstrated, during the process of change from subsistence farming to a market economy prices were increasingly conditioned by international trade and other factors.

\section{DISCUSSION}

The four English gross-production series of wheat from 1640 to 1761 (I, II, III and IV) are presented in Graphs 1 and 2. They show a range between the most optimistic (II) and the most pessimistic (III) series. To determine which comes closest to existing evidence, we compared them with the database provided by probate inventories and farm accounts (Tables 2 to 6 ).

\section{GRAPHS 1 AND 2}

\section{English gross production of wheat in millions of bushels, 1640-1761}

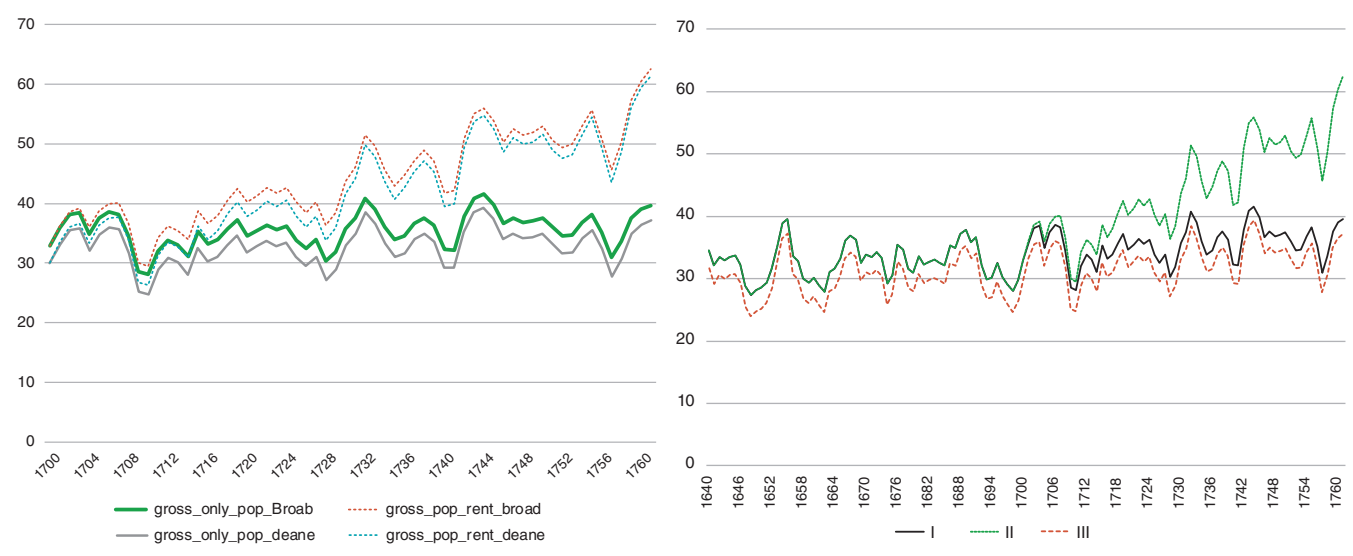

Sources: our own calculation, from the following sources and methods. Series I (gross_only_pop_broad) is obtained with 27.94 million net bushels provided by Broadberry et al. (2015) c. 1700, applying Davenant's Law with Clark $(2004,2005,2007)$ prices, and adding population (Wrigley \& Schofield, 1981), as well as $2.5 \mathrm{bu} / \mathrm{acre}$ of seeds and other uses. Series II (gross_pop_rent_broad) also adds income variation (based on British GDP by Broadberry et al., 2015) corrected with the average value 0.4, adding 2.5 bu/acre of seeds and other uses. Series III (gross_only_pop_deane) takes the gross datum provided by Deane and Cole (1967) for 1700 as a starting point, applying Davenant's Law and adding population. Series IV (gross_pop_rent_deane) adds the income evolution corrected with 0.4 to series III.

According to these results, between 1640 and 1761 average wheat yields were 18.1 $\mathrm{bu} / \mathrm{acre}$. The first thing we observe is that the four series correlate well with this baseline and that their implicit yields range from 15.9 to $19.9 \mathrm{bu} / \mathrm{acre}$. Series I and IV present a lower deviation $(-4.5 \%$ and $+3.4 \%)$. If we adjust the surface area of land cultivated with wheat for each series to the yields obtained on the farms, we also observe that I and IV 
have the best fit to the available estimates, and especially series I with a deviation of only $1 \%$. The feeling that series I is the best fit is confirmed by comparing the total outputs estimated by other authors, where the deviation is only $4 \%$.

TABLE 2

Comparison with English wheat series estimated from probate inventories and farm accounts, 1640-1761

\begin{tabular}{lccc}
\hline SERIES & Estimated yield & Deviation & Correlation \\
\hline BROAD_POP (I) & 17.3 bu/acre & $-4.5 \%$ & 0.66 \\
BROAD_POP_RENT (II) & 19.9 bu/acre & $10.2 \%$ & 0.75 \\
DEANE_POP (III) & 15.9 bu/acre & $-12.3 \%$ & 0.65 \\
DEANE_POP_RENT (IV) & 18.7 bu/acre & $3.4 \%$ & 0.74 \\
\hline
\end{tabular}

Source: our own calculation. Between 1640 and 1761 average wheat yields from probate inventories and farm accounts were $18.1 \mathrm{bu} / \mathrm{acre}$.

TABLE 3

English Land surface cultivated with wheat (millions of acres) necessary to fit the yields of the four estimated series to those obtained from probate inventories and farm accounts, 1640-1761

\begin{tabular}{lcc}
\hline SERIES & Cultivated area required, in millions of acres & Deviation \\
\hline BROAD_POP (I) & 2.01 & $1 \%$ \\
BROAD_POP_RENT (II) & 2.27 & $14 \%$ \\
DEANE_POP (III) & 1.85 & $-7 \%$ \\
DEANE_POP_RENT (IV) & 2.12 & $6 \%$ \\
\hline
\end{tabular}

Source: our own calculation. Average surface stated by Broadberry et al. (2015) between 1650 and $1750=$ 2 million acres.

\section{TABLE 4}

Comparison of our English series of wheat production with outputs estimated by other authors, 1645-1761

\begin{tabular}{lccc}
\hline SERIES & Average estimated output & Deviation & Correlation coefficient \\
\hline BROAD_POP (I) & 32.1 & $4.0 \%$ & 0.80 \\
BROAD_POP_RENT (II) & 37.5 & $21.6 \%$ & 0.89 \\
DEANE_POP (III) & 29.3 & $-5.1 \%$ & 0.82 \\
DEANE_POP_RENT (IV) & 35.0 & $13.6 \%$ & 0.89 \\
\hline
\end{tabular}

Source: our own calculation from the sources and methods explained in Table 1. 
The conclusion is simple. Series I, that is, the one calculated from physical estimates originating in Broadberry et al. (2015) with Davenant's price elasticity and the population trend (using 1700 as a year of average harvest throughout the period) is the one with the best fit. This is based on two main facts. The first is that the wheat component of the agricultural GDP estimated by Broadberry et al. (2015) seems very reliable. The second is about the elasticities. The price elasticities of the different demand curves are $-0.39 /-0.38$ in I, $-0.33 /-0.39$ in II, $-0.47 /-0.46$ in III, and $-0.40 /-0.47$ in IV (Tables 5 and 6). On the other hand, income elasticity is nearly zero in I and III, and 0.6/0.7 in II and IV.

TABLE 5

Price and income elasticities of English wheat consumption calculated through the Cobb-Douglas method, 1645-1761

\begin{tabular}{lcc}
\hline SERIES & Price elasticity & Income elasticity \\
\hline BROAD_POP (I) & -0.39 & 0 \\
BROAD_POP_RENT (II) & -0.33 & 0.59 \\
DEANE_POP (III) & -0.47 & 0 \\
DEANE_POP_RENT (IV) & -0.40 & 0.68 \\
\hline
\end{tabular}

Source: our own calculation. Cobb-Douglas method has been applied.

\section{TABLE 6}

Price elasticity of English wheat consumption obtained through differences and logarithms, 1645-1761

\begin{tabular}{lc}
\hline SERIES & Price elasticity \\
\hline BROAD_POP (I) & -0.38 \\
BROAD_POP_RENT (II) & -0.39 \\
DEANE_POP (III) & -0.46 \\
DEANE_POP_RENT (IV) & -0.47 \\
\hline
\end{tabular}

Source: our own calculation. Price and production series differentiation method has been applied.

If series I is the closest to the estimates obtained from farm accounts and probate inventories, it means that Davenant's equation and its elasticity are not mere idle speculation. The equation fits with Campbell and Ó Gráda's (2011) estimates, since it is halfway along the decreasing trend of harvest variability from the Middle Ages to the $19^{\text {th }}$ century. Income elasticity has little significance between 1645 and 1761, proving this to be an age when rent was not a relevant component of consumption decisions. If we tried instead a 0.5 to 0.7 income elasticity of wheat consumption, as has sometimes been claimed, we would move away from the estimates obtained from a large set of farm accounts and probate inventories accumulated during the last forty years. In fact, this would involve an unreliable national wheat yield of $31.2 \mathrm{bu} /$ acre (according to our series II), much higher than 
the 22.4 provided by Michael Turner et al. (2001) for the years 1750-59, the 20 provided by Robert Allen (2005) for 1750, and the 20.1 by Jonathan Theobald (2002) also for 1750 . The only way to consider income a significant demand factor throughout the period from 1640 to 1761 in a way that might fit the available estimates, and our own results, would be to assume a higher average of wheat cultivated area of around $10 \%$, or the part allocated to seeds and other uses being 50\% lower than the ones considered here-something that would require significant advances in empirical studies based on local sources to allow a profound change in current assumptions.

\section{GRAPH 3}

Gross yields in bu/acre of our series $\mathrm{V}$ of English wheat production, compared to those resulting from other site-specific sources indicated in the previous tables, $1760-1870$

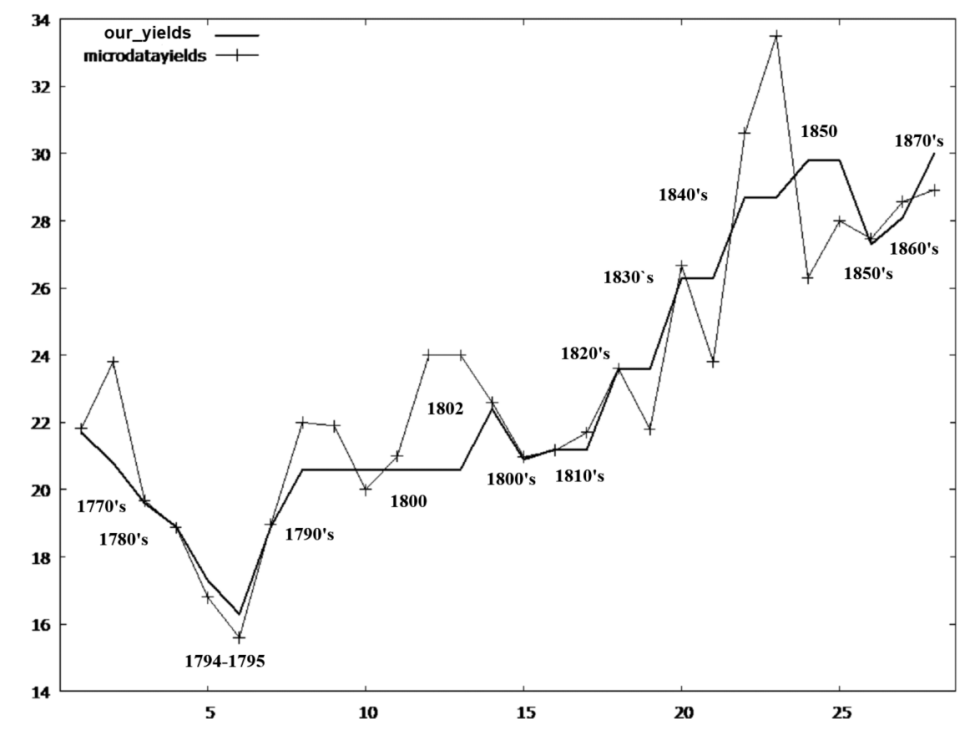

Source: our own calculation.

The above does not preclude the existence of a structural change during the second half of the $18^{\text {th }}$ century, through which income elasticity would have gained momentum along with the growing income per capita. If we try to incorporate this ascending effect in series I, lengthening it until 1850 with an average income elasticity of 0.6 (that is, close to 0 until the mid- $18^{\text {th }}$ century and growing to 1 in the $19^{\text {th }}$ century), we see how the evolution of the wheat output, demand and yields obtained fit the trends observed by economic historians so far (series V and VI, Graphs 3 and 5, Table 7). The correlation coefficient between our gross yield estimations of wheat per acre and those observed in the main 
sources is $90 \%$, and average deviation between them is only $1 \%$. These results have been obtained through a logarithmic regression model of the series between 1640 and 1870: we obtain a non-linear equation of $D_{\text {wheat }}=P_{\text {wheat }}^{-0,65} P_{\text {agric }}^{0,8} I^{0,6}$, where $D_{\text {wheat }}$ stands for the national demand of wheat in bushels, $P_{\text {wheat }}$ stands for wheat prices, $P_{\text {agric }}$ is the centennial index of agricultural prices and $I$ stands for the British centennial GDP (Broadberry et al., 2015). The addition of the three elasticities is not equal to zero, since we are not in perfect competition.

However, the accuracy of these results depends to a high degree on two variables: the wheat cultivated area and the difference between the gross and net outputs; that is, the resulting quantity after deducting the part allocated to seeds, personal consumption, payments in kind, animal feeding or losses. This stands true for the whole period analysed here. The number of acres of land used in wheat cultivation is unknown, but there is evidence that demographic pressure, together with prices and income changes, strongly affected its evolution in the long term. All published researches assume that from the second half of the $17^{\text {th }}$ century on, the wheat cultivated area grew steadily until soon after the massive introduction of the American grain imports during the 1870s and 1880s. Robert Allen (2005) provided the estimates of 1.4 million of acres in 1700, 2.1 in 1750, 2.5 in 1800, and 3.6 in 1850. The statistical series of wheat cropland surface began in 1867 with 3.37 million acres.

Regarding the difference between net and gross yields per acre, what we can say on the whole is that this difference must have been between 2 and 2.5. Peter J. Bowden (1985) provided some site-specific estimates on wheat harvest detraction of seeds for sowing and animal feeding ranging from 2.25 to 3.37 bushels/acre between 1670 and 1745 . Mark Overton (1984) quoted Bennet (2-2.5 bu/acre) and King (who estimated a range of seedyield ratios from 1:4 to $1: 8$ ). Anthony Wrigley (1987) suggested a reference value of 2.5 (quoting Bowden and Slicher van Bath), plus 1 in other cereals for cattle-feeding. In some passages in their writings on agriculture, Robert Plot and John Mortimer claimed that farmers sowed between 2 and $2.5 \mathrm{bu} / \mathrm{acre}$ of wheat, or $2 \mathrm{bu} / \mathrm{acre}$ in poor soils and 3 in the most productive, respectively (Plot, 1705: 250; Mortimer, 1712: 95). All of these estimates exclude personal consumption, payments in kind or simply losses within farms.

Our series can also be compared with the crop estimates provided by English agricultural historiography. William G. Hoskins (1968: 20-2) described as deficient those crops from the years 1646, 1657, 1710, and 1711; as bad or very bad crops those from the years $1647,1648,1649,1658,1661,1662,1673,1674,1678,1692,1693,1695,1696,1697$, $1698,1708,1709,1714,1727,1728$, and 1729; as "average" crops those from the years $1699,1700,1718,1719$, and 1720; and as good crop years those from 1652, 1653, 1654, 
TABLE 7

Comparison of different estimates of English wheat yields, 1760-1879

\begin{tabular}{|c|c|c|c|c|}
\hline $\begin{array}{r}\text { Ou } \\
\text { (gro }\end{array}$ & $\begin{array}{l}\text { Our estimates } \\
\text { gross, bu/acre) }\end{array}$ & $\begin{array}{c}\text { Other authors } \\
\text { (gross, bu/acre) }\end{array}$ & Deviation & Authors \\
\hline $1760-69$ & 21.7 & 21.82 & $0.5 \%$ & Turner et al. (2001) \\
\hline 1770 & 20.8 & 23.80 & $12.6 \%$ & Artur Young (John, 1986) \\
\hline $1770-79$ & 19.6 & 19.68 & $0.4 \%$ & Turner et al. (2001) \\
\hline $1780-89$ & 18.9 & 18.88 & $-0.1 \%$ & Turner et al. (2001) \\
\hline 1794 & 17.3 & 16.8 & $-3.0 \%$ & Harvest inquiry (John, 1986) \\
\hline 1795 & 16.3 & 15.6 & $-4.5 \%$ & Harvest inquiry (John, 1986) \\
\hline $1790-99$ & 18.9 & 18.97 & $0.4 \%$ & Turner et al. (2001) \\
\hline 1800 & 20.6 & 22 & $6.4 \%$ & Oxon (Allen, 2005) \\
\hline 1800 & 20.6 & 21.9 & $5.9 \%$ & Harvest inquiry (John, 1986) \\
\hline 1800 & 20.6 & 20 & $-3.0 \%$ & England (Allen, 2005) \\
\hline 1800 & 20.6 & 21 & $1.9 \%$ & Hants (Glennie, 1991) \\
\hline 1800 & 20.6 & 24 & $14.2 \%$ & Herts (Glennie, 1991) \\
\hline 1800 & 20.6 & 24 & $14.2 \%$ & Holderness (1989) \\
\hline 1802 & 22.4 & 22.6 & $0.9 \%$ & Crop Ret. (Turner et al., 2001) \\
\hline $1800-09$ & 20.9 & 20.98 & $0.4 \%$ & Turner et al. (2001) \\
\hline $1810-19$ & 21.2 & 21.17 & $-0.1 \%$ & Turner et al. (2001) \\
\hline $1810-19$ & 21.2 & 21.7 & $2.3 \%$ & Healy and Jones (1962) \\
\hline $1820-29$ & 23.6 & 23.6 & $0.0 \%$ & Turner et al. (2001) \\
\hline $1820-29$ & 23.6 & 21.8 & $-8.3 \%$ & Healy and Jones (1962) \\
\hline $1830-39$ & 26.3 & 26.67 & $1.4 \%$ & Turner et al. (2001) \\
\hline $1830-39$ & 26.3 & 23.8 & $-10.5 \%$ & Healy and Jones (1962) \\
\hline $1840-49$ & 28.7 & 30.6 & $6.2 \%$ & Turner et al. (2001) \\
\hline $1840-49$ & 28.7 & 33.5 & $14.3 \%$ & Healy and Jones (1962) \\
\hline 1850 & 29.8 & 26.3 & $-13.3 \%$ & Craigie (1883; from Turner et al., 2001) \\
\hline 1850 & 29.8 & 28 & $-6.4 \%$ & Allen (2005) \\
\hline $1850-59$ & 27.3 & 27.47 & $0.6 \%$ & Turner et al. (2001) \\
\hline $1860-69$ & 28.1 & 28.57 & $1.6 \%$ & Turner et al. (2001) \\
\hline $1870-79$ & 30 & 28.92 & $-3.7 \%$ & Turner et al. (2001) \\
\hline Mean & 23.03 & 23.36 & $1.1 \%$ & \\
\hline Median & 21.2 & 22.3 & $0.5 \%$ & \\
\hline Minimum & 16.3 & 15.6 & $-13.3 \%$ & \\
\hline Maximum & 30 & 33.5 & $14.3 \%$ & \\
\hline Standard deviation & ion $\quad 4.07$ & 4.160 & 0.07 & \\
\hline C.V. & 0.177 & 0.178 & 6.23 & \\
\hline
\end{tabular}

Source: our own calculation. The correlation coefficient between the two columns is 0.9 . 
$1655,1665-72$, together with the 1680 s, generally good, as well as the periods $1700-07$ and 1721-23. Peter Bowden (1985:56) suggested the existence of bad crops in the second half of the $17^{\text {th }}$ century in the periods $1645-51,1656-63,1695-99$ and good crops in the periods 1664-72, 1685-91, 1714-24, and 1741-49. Our series fits the period 1640-1750 quite well (Table 8).

\section{GRAPH 4}

Long-term evolution of English wheat yields in bu/acre, from 1645 to 1850

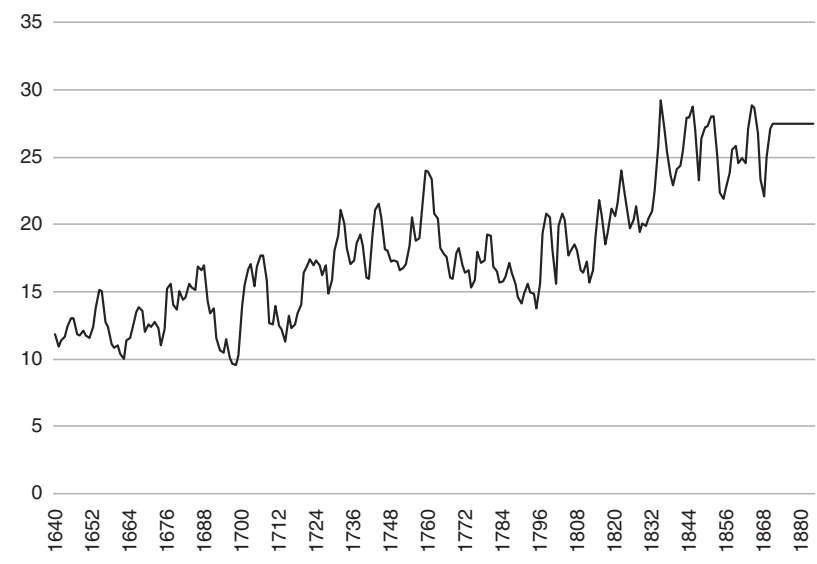

— WHEAT NET YIELDS, BU/ACRE

Source: our own calculation.

\section{GRAPH 5}

Long-term comparison of our estimates of English wheat output and demand in millions of bushels (series V and VI)

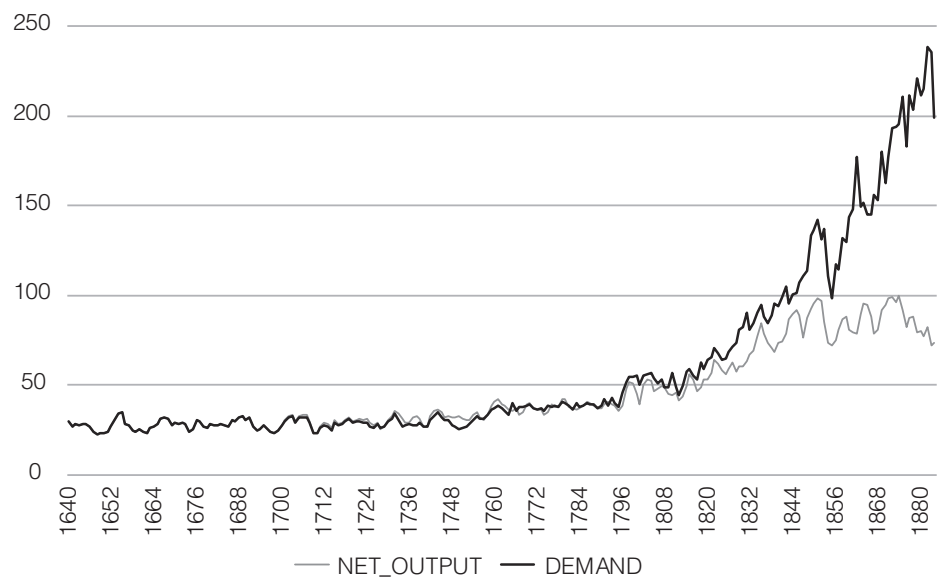

Source: our own calculation. 


\section{TABLE 8}

Comparison of the variation of our English series of gross wheat output with the available chronology of the character of harvests, 1645-1749

\begin{tabular}{llc}
\hline Hoskins & Years & Wheat gross output (bushels) \\
\hline Deficient crops & $1646,1657,1710,1711$ & $31,306,518(-8.8 \%)$ \\
Bad and very bad crops & $1647,1648,1649,1658,1661,1662$, & \\
& $1673,1674,1678,1692,1693,1695$, & $30,330,181(-11.6 \%)$ \\
& $1696,1697,1698,1708,1709,1714$, & \\
Average crops & $1727,1728,1729$ & $34,302,075$ \\
Good years & $1699,1700,1718,1719,1720$ & \\
& $1652,1653,1654,1655,1665-72$, & $35,332,446(+3 \%)$ \\
\hline Bowden & 1680 s generally good, 1700-07 & \\
\hline Bad crops & and 1721-23 & Wheat gross output (bushels) \\
& Years & $29,696,256$ \\
Good crops & $1645-51$ & $30,491,192$ \\
& $1656-63$ & $29,886,137$ \\
& $1695-99$ & $34,251,154$ \\
& $1664-72$ & $35,718,380$ \\
& $1685-91$ & $34,976,126$ \\
\hline
\end{tabular}

Source: our own calculation.

This verification can be completed by comparing Table 8 with the sequence of food riots studied by John Bohstedt (2010), a clear coincidence being observed with the worst production years. Furthermore, our annual series of wheat production also allows us to clear up some discrepancies. For example, Hoskins claimed that 1699 was an average year, whereas Bowden considered it bad. Who was right? Our results are 29.7 million bushels, a low figure. Therefore, it would appear that Bowden was closer to reality.

\section{CONCLUSIONS}

This article presents the first estimation of the English annual series of wheat production, yields (considering acreage) and demand (adding foreign net trade balance) for a period for which these data are unknown: 1645-1761. The methodology applied is based on the price elasticity in England calculated by Charles Davenant in 1699, anchoring the series on the "usual" average harvest of 1700 and setting a long-term trend based on population and income growth in a way that allows supply and demand to be integrated by con- 
sidering a slow increase in income elasticity from 1750 onwards. The results match the available estimates on yields and harvests gathered from site-specific farm accounts and probate inventories from that period, and also indicate that the starting points used by Broadberry et al. (2015) to build up the agricultural GDP in 1700 are reliable, at least in the case of wheat.

Through this exercise, Davenant's Law has been revealed to be much more accurate than just guesswork, probably because it was based on well-grounded empirical knowledge of British traders at the time. The series generated fits well with the independent sources available and confirms both the decreasing trend of price elasticity in the very long term (Campbell \& Ó Gráda, 2011) and historiography on the variability of wheat crops (Hoskins, 1968; Bowden, 1985; Bohstedt, 2010).

The estimates carried out in the article suggest that income elasticity had little significant effect on consumption decisions, at least until the mid- $18^{\text {th }}$ century, increasing in importance at a later date. If we lengthen the series to the year when official statistics began in 1884, assuming an income elasticity of 0.6 for the whole period 1645-1884, the trend fits the available estimates on yields and output. The series confirms that wheat production and yields evolved negatively during the second half of the $18^{\text {th }}$ century, and took off dramatically in the $19^{\text {th }}$ century. Accordingly, seen from a production and yields perspective, the Agricultural Revolution seems to have taken place in two very different periods, before 1750 and after 1800 .

However, many questions remain open. The change in surface area cultivated with wheat must be better studied. It is necessary to consider possible changes in the percentage allocated to seeds in more detail, as well as their uses other than market sale. The new estimates should also be extended to other cereals until 1884 . The reasons behind the structural breakpoint found around 1761 must also be found, when wheat yields started to fall, total wheat production slowed down, England became a net importer, prices rocketed, and physical wheat consumption per head fell, despite bread intake remaining more stable thanks to substitution among grains.

\section{ACKNOWLEDGMENTS}

The authors thank to the participants in the first seminars where this article was presented as early working paper: "Old and New Worlds: The Global Challenges of Rural History", ISCTEIUL (University Institute of Lisbon, January 2016), and the PhD Seminar on Economic History at the University of Barcelona (February 2016). Also, authors thank to the 
anonymous reviewer of Historia Agraria for his contributions to improve this article. This work has been funded by the Spanish projects HAR2014-54891-P and HAR201569620-C2-1-P, and the international Partnership Grant SSHRC 895-2011-1020 on "Sustainable Farm Systems: Long-Term Socio-ecological Metabolism in Western Agriculture" funded by the Social Sciences and Humanities Research Council of Canada.

\section{REFERENCES}

ABLER, D. (2010). Demand Growth in Developing Countries. OECD Food, Agriculture and Fisheries Papers, (29). http://dx.doi.org/10.1787/5km91p2xcsd4-en

Allen, R. C. (1988). The Growth of Labor Productivity in Early Modern English Agriculture. Explorations in Economic History, 25 (2), 117-46.

Allen, R. C. (1989). Enclosure, Farming Methods and the Growth of Productivity in the South Midlands. In G. Grantham \& C. S. Leonard (Eds.), Agrarian Organization in the Century of Industrialization: Europe, Russia, and North America (pp. 6988). Greenwich: Jai Pr. (Research in Economic History, suppl. 5).

AlleN, R. C. (1991). The Two English Agricultural Revolutions, 1450-1850. In B. S. M. CAMPBEll \& M. OverTon (Eds.), Land, Labour and Livestock: Historical Studies in European Agricultural Productivity (pp. 236-54). Manchester: Manchester University Press.

Allen, R. C. (1999). Tracking the Agricultural Revolution in England. Economic History Review, (52), 209-35.

Allen, R. C. (2005). English and Welsh Agriculture, 1300-1850: Outputs, Inputs and Income. Oxford University Working Papers.

Allen, R. C. (2007). Pessimism Preserved: Real Wages in the British Industrial Revolution. Oxford University Working Papers.

Allen, R. C. (2008). The Nitrogen Hypothesis and the English Agricultural Revolution: A Biological Analysis. The fournal of Economic History, 68 (1), 182-210.

Allen, R. C. (2009). The British Industrial Revolution in Global Perspective. Cambridge: Cambridge University Press.

Appleby, A. B. (1979). Grain Prices and Subsistence Crises in England and France, 15901740. The fournal of Economic History, 39, (4), 865-87.

BARquín, R. (2005). The Elasticity of Demand for Wheat in the $14^{\text {th }}$ to $18^{\text {th }}$ Centuries. Revista de Historia Económica-fournal of Iberian and Latin American Economic History, 23 (2), 241-68.

Bohstedt, J. (2010). The Politics of Provisions: Food Riots, Moral Economy and Market Transition in England, 1550-1850. Farnham: Ashgate. 
Bowden, P. (1985). Agricultural Prices, Wages, Farm Profits, and Rents. In J. THIRSK (Ed.), The Agrarian History of England and Wales. 5: 1640-1750. Part 2: Agrarian Change (pp. 1-117). Cambridge: Cambridge University Press.

Broadberry, S., Campbell, B. M. S., Klein, A., Overton, M. \& Van Leeuwen, B. (2015). British Economic Growth, 1270-1870. Cambridge: Cambridge University Press.

BRUNT, L. (2004). Nature or Nurture? Explaining English WheatYields in the Industrial Revolution, c. 1770. The fournal of Economic History, 64 (1), 193-225.

BRUNT, L. (2015). Weather Shocks and English Wheat Yields, 1690-1871. Explorations in Economic History, (57), 50-58.

CAIRD, J. (1852). English Agriculture. London: Cassell.

CAmpBell, B. M. S. \& Ó GrÁdA, C. (2011). Harvest Shortfalls, Grain Prices, and Famines in Preindustrial England. The fournal of Economic History, 71 (4), 859-86.

Chartres, J. A. (1985). The Marketing of Agricultural Produce. In J. THIRSK (Ed.), The Agrarian History of England and Wales. 5: 1640-1750. Part 2: Agrarian Change (pp. 406-502). Cambridge: Cambridge University Press.

Chartres, J. A. (1995). Market Integration and Agricultural Output in Seventeenth-, Eighteenth-, and early Nineteenth-Century England. The Agricultural History Review, 43 (2), 117-38.

Clark, G. (2002). The Agricultural Revolution and the Industrial Revolution: England, 1500-1912. University of California Working Paper.

Clark, G. (2004). The Price History of English Agriculture, 1209-1914. Research in Economic History, (22), 41-124.

Clark, G. (2005). The Condition of the Working-Class in England, 1209-2004. Fournal of Political Economy, 113 (6), 1307-40.

Clark, G. (2007). The Long March of History: Farm Wages, Population and Economic Growth, England 1209-1869. Economic History Review, 60 (1), 97-135.

Clark, G., Cummings, J. \& Smith, B. (2010). The Surprising Wealth of Pre-industrial England. SSRNWorking Paper. https://papers.ssrn.com/sol3/papers.cfm?abstract_id= 1653154

Collins, E. J.T. (1975). Dietary Change and Cereal Consumption in Britain in the Nineteenth Century. The Agricultural History Review, 23 (2), 97-115.

Comber, W.T. (1808). An Inquiry into the State of National Subsistence as connected with the Progress of Wealth and Population. London:T. Cadell \& W. Davis.

CRAFTS, N. F. R. (1980). Income Elasticities of Demand and the Release of Labor by Agriculture during the British Industrial Revolution: A Further Appraisal. Fournal of European Economic History, (9), 153-68. 
Davenant, C. (1771 [1699]). An Essay upon the Probable Methods of Making a People Gainers in the Balance of Trade. In C. Whitworth (Ed.), The Political and Commercial Works of Charles Davenant. London: R. Horsfield.

DAvies, D. (1795). The Case of Labourers in Husbandry. London: C. G. \& J. Robinson.

DeAne, P. \& Cole, W. A. (1967). British Economic Growth, 1688-1959, Trends and Structure. $2^{\text {nd }}$ ed. Cambridge: Cambridge University Press.

EDEN, F. M. (1797). The State of the Poor. London: Cass.

Endres, A. M. (1987). The King-Davenant "Law" in Classical Economics. History of Political Economy, 19 (4), 621-38.

FogEL, R.W. (2004). The Escape from Hunger and Premature Death, 1700-2100: Europe, America, and the Third World. Cambridge: Cambridge University Press.

GLENNIE, P. (1991). Measuring Crop Yields in Early Modern England. In B. M. S. CAMPBELL \& M. OverTon (Eds.), Land, Labour and Livestock: Historical Studies in European Agricultural Productivity (pp. 255-83). Manchester: Manchester University Press.

Healy, M. J. R. \& Jones, E. L. (1962). Wheat Yields in England, 1815-59. Fournal of the Royal Statistical Society. Series A (General), 125 (4), 574-79.

HiPkIN, S. (2012). The Coastal Metropolitan Corn Trade in Later Seventeenth Century England. The Economic History Review, 65 (1), 220-55.

Holderness, B. A. (1989). Prices, Productivity, and Output. In G. E. MingaY (Ed.), The Agrarian History of England and Wales. 6: 1750-1850 (pp. 1-118). Cambridge: Cambridge University Press.

Hoskins, W. G. (1968). Harvest Fluctuations and English Economic History, 1620-1759. The Agricultural History Review, 16 (1), 15-31.

HoyLe, R. W. (2013). Why was there no Crisis in England in the 1690's? In R. W. HoyLE (Ed.), The Farmer in England, 1650-1980 (pp. 69-100). London: Routledge.

Hutchison, T.W. (1988). Before Adam Smith:The Emergence of Political Economy, 16621776. Oxford: Blackwell.

John, A. H. (1986). Statistical Appendix. In G. E. Mingay (Ed.), The Agrarian History of England and Wales. 6: 1750-1850 (pp. 972-1155). Cambridge: Cambridge University Press.

Jones, E. L. (1965). Agriculture and Economic Growth in England, 1660-1750: Agricultural Change. The fournal of Economic History, 25 (1), 1-18.

KaIn, R. J. P. \& Prince, H. C. (2006). The Tithe Surveys of England and Wales. Cambridge: Cambridge University Press.

Kelly, M. \& Ó GrÁDA, C. (2013). Numerare Est Errare: Agricultural Output and Food Supply in England Before and During the Industrial Revolution. The fournal of Economic History, 73 (4), 1132-163.

KERRIDGE, E. (1967). The Agrarian Revolution. London: George Allen \& Unwin. 
Lawes, J. B. \& Gilbert, J. H. (1893). Home produce, Imports, Consumption and Price of Wheat over 40 Harvest-Years, 1852-3 to 1891-2. London: Spottiswoode.

Mrtchell, B. R. (1988). British Historical Statistics. Cambridge: Cambridge University Press.

Mortimer, J. (1712). The Whole Art of Husbandry: Or, the Way of Managing and Improving of Land. Being a Full Collection of what Hath Been Writ, Either by Ancient Or Modern Authors:... As Also an Account of the Particular Sorts of Husbandry Used in Several Counties;... To which is Added, the Country-man's Kalendar. London: R. Robinson.

NeILD, W. (1841). Comparative Statement of the Income and Expenditure of Certain Families of the Working Classes in Manchester and Duckenfield, in theYears 1836 and 1841. Fournal of the Statistical Society of London, 4 (4), 320-34.

Nielsen, M., SMIT, J. \& Guillén, J. (2012). Price Effects of Changing Quantities Supplied at the Integrated European Fish Market. Marine Resource Economics, 27 (2), $165-80$.

Ormrod. D. (1985). English Grain Exports and the Structure of Agrarian Capitalism, 1700-1760. Hull: Hull University Press.

Overton, M. (1979). Estimating Crop Yields from Probate Inventories: An Example from East Anglia, 1585-1735. The fournal of Economic History, 39 (2), 363-78.

Overton, M. (1984). Agricultural Productivity in Eighteenth-Century England: Some Further Speculations. The Economic History Review, 37 (2), 252-57.

Overton, M. (1991). The Determinants of Crop Yields in Early Modern England. In B. M. S. CAMPBell \& M. OverTon (Eds.), Land, Labour and Livestock: Historical Studies in European Agricultural Productivity. Manchester: Manchester University Press.

Overton, M. (1996a). Re-Establishing the English Agricultural Revolution. The Agricultural History Review, 44 (1), 1-20.

Overton, M. (1996b). Agricultural Revolution in England: The Transformation of the Agrarian Economy, 1500-1850. Cambridge: Cambridge University Press.

Parenti, G. (1942). Prezzi e mercato del grano a Siena, 1546-1765. Firenze: C. Cya.

Persson, K. G. (1999). Grain Markets in Europe, 1500-1900: Integration and Deregulation. Cambridge: Cambridge University Press.

Petersen, C. (1995). Bread and the British Economy, c 1770-1870. Aldershot: Scholar Press.

PetTy,W. (1927 [1687]). The Petty Papers: Some UnpublishedWritings of SirWilliam Petty. London: Constable.

Plot, R. (1705 [1676]). The Natural History of Oxford-Shire, Being an Essay towards the Natural History of England. London: Leon Lischfield, for Charles Brome and J. Nicholson. 
Rogers, J. E. T. (1877). A History of Agriculture and Prices in England. 6: 1583-1702. Oxford: Clarendon.

SimONin, J. P. (1996). Des premiers énoncés de la loi de King à sa remise en cause: Essais de mesures ou fictions théoriques. Histoire E Mesure, 11 (3-4), 213-54.

Slicher van Bath, B. H. (1963). The Agrarian History of Western Europe: A. D. 500-1850. London: Edward Arnold.

Tello, E., Martínez, J. L., Jover, G., Olarieta, J. R., García Ruiz, R., González de Molina, M., Badia, M., Winiwarter, V. \& Koepke, N. (2017). The Onset of the English Agricultural Revolution: Climate Factors and Soil Nutrients. The fournal of Interdisciplinary History, 47 (4), 445-74.

Theobald, J. (2002). Agricultural Productivity in Woodland High Suffolk, 1600-1850. The Agricultural History Review, 50 (1), 1-24.

Tooke, T. \& Newmarch, W. (1838). A History of Prices, and of the State of the Circulation, from 1793 to 1837. London: Longman, Orme, Brown, Green, and Longmans. Turner, M. (1982). Agricultural Productivity in England in the Eighteenth Century: Evidence from Crop Yields. The Economic History Review, 35 (4), 489-510.

Turner, M. (1986). English Open Fields and Enclosures: Retardation or Productivity Improvements. The Fournal of Economic History, 46 (3), 669-92.

Turner, M. E., Becket, J.V. \& Afton, B. (1997). Agricultural Rent in England, 16901914. Cambridge: Cambridge University Press.

Turner, M. E., BeCKet, J. V. \& AFton, B. (2001). Farm Production in England, 17001914. Oxford: Oxford University Press.

Uebele, M., GrÜnebaum, T. \& Kopsidis, M. (2013). King's Law and Food Storage in Saxony, c. 1790-1830. Center for Quantitative Economics Working Papers, (26).

Wrigley, E. A. (1987). People, Cities and Wealth. Oxford: Blackwell.

Wrigley, E. A. \& SCHOFIELD, R. S. (1981). The Population History of England, 15411871: A Reconstruction. Cambridge: Cambridge University Press.

Yelling, J. A. (1970). Probate Inventories and the Geography of Livestock Farming: A Study of East Worcestershire, 1540-1750. Transactions of the Institute of British Geographers, (51), 111-26.

YelLING, J. A. (1973). Changes in Crop Production in East Worcestershire 1540-1867. Agricultural. History Review, 21 (1), 18-34. 


\section{APPENDIX}

\begin{tabular}{|c|c|c|c|}
\hline \multicolumn{2}{|r|}{ WHEAT GROSS OUTPUT } & \multicolumn{2}{|r|}{ WHEAT GROSS OUTPUT } \\
\hline YEAR & (BROAD_POP, SERIES I) & YEAR & (BROAD_POP, SERIES I) \\
\hline \multicolumn{2}{|r|}{ Million bushels } & \multicolumn{2}{|r|}{ Million bushels } \\
\hline 1640 & 34.5 & 1674 & 29.2 \\
\hline 1641 & 32.2 & 1675 & 30.5 \\
\hline 1642 & 33.5 & 1676 & 35.5 \\
\hline 1643 & 32.9 & 1677 & 34.6 \\
\hline 1644 & 33.5 & 1678 & 31.6 \\
\hline 1645 & 33.7 & 1679 & 31.0 \\
\hline 1646 & 32.3 & 1680 & 33.6 \\
\hline 1647 & 28.8 & 1681 & 32.3 \\
\hline 1648 & 27.3 & 1682 & 32.7 \\
\hline 1649 & 28.1 & 1683 & 33.1 \\
\hline 1650 & 28.5 & 1684 & 32.6 \\
\hline 1651 & 29.3 & 1685 & 32.2 \\
\hline 1652 & 31.6 & 1686 & 35.3 \\
\hline 1653 & 35.3 & 1687 & 34.9 \\
\hline 1654 & 38.9 & 1688 & 37.2 \\
\hline 1655 & 39.6 & 1689 & 37.8 \\
\hline 1656 & 33.6 & 1690 & 35.9 \\
\hline 1657 & 32.8 & 1691 & 36.7 \\
\hline 1658 & 30.0 & 1692 & 32.1 \\
\hline 1659 & 29.3 & 1693 & 29.9 \\
\hline 1660 & 30.2 & 1694 & 30.1 \\
\hline 1661 & 28.9 & 1695 & 32.5 \\
\hline 1662 & 27.9 & 1696 & 30.3 \\
\hline 1663 & 31.1 & 1697 & 29.1 \\
\hline 1664 & 31.6 & 1698 & 28.0 \\
\hline 1665 & 33.2 & 1699 & 29.7 \\
\hline 1666 & 36.1 & 1700 & 32.9 \\
\hline 1667 & 36.9 & 1701 & 35.9 \\
\hline 1668 & 36.2 & 1702 & 38.1 \\
\hline 1669 & 32.6 & 1703 & 38.5 \\
\hline 1670 & 33.9 & 1704 & 34.9 \\
\hline 1671 & 33.5 & 1705 & 37.5 \\
\hline 1672 & 34.3 & 1706 & 38.6 \\
\hline 1673 & 33.3 & 1707 & 38.2 \\
\hline
\end{tabular}




\begin{tabular}{|c|c|c|c|}
\hline \multirow{2}{*}{\multicolumn{2}{|c|}{$\begin{array}{l}\text { WHEAT GROSS OUTPUT } \\
\text { (BROAD_POP, SERIES I) }\end{array}$}} & \multicolumn{2}{|r|}{ WHEAT GROSS OUTPUT } \\
\hline & & YEAR & (BROAD_POP, SERIES I) \\
\hline & Million bushels & \multicolumn{2}{|r|}{ Million bushels } \\
\hline 1708 & 34.5 & 1742 & 37.9 \\
\hline 1709 & 28.5 & 1743 & 40.9 \\
\hline 1710 & 28.1 & 1744 & 41.6 \\
\hline 1711 & 32.0 & 1745 & 39.8 \\
\hline 1712 & 33.8 & 1746 & 36.7 \\
\hline 1713 & 33.0 & 1747 & 37.6 \\
\hline 1714 & 31.1 & 1748 & 36.8 \\
\hline 1715 & 35.3 & 1749 & 37.1 \\
\hline 1716 & 33.2 & 1750 & 37.5 \\
\hline 1717 & 33.9 & 1751 & 36.0 \\
\hline 1718 & 35.7 & 1752 & 34.5 \\
\hline 1719 & 37.2 & 1753 & 34.7 \\
\hline 1720 & 34.6 & 1754 & 36.8 \\
\hline 1721 & 35.5 & 1755 & 38.2 \\
\hline 1722 & 36.4 & 1756 & 35.2 \\
\hline 1723 & 35.6 & 1757 & 30.9 \\
\hline 1724 & 36.2 & 1758 & 33.6 \\
\hline 1725 & 33.8 & 1759 & 37.6 \\
\hline 1726 & 32.5 & 1760 & 39.0 \\
\hline 1727 & 33.9 & 1761 & 39.6 \\
\hline 1728 & 30.3 & & \\
\hline 1729 & 31.9 & & \\
\hline 1730 & 35.7 & & \\
\hline 1731 & 37.5 & & \\
\hline 1732 & 40.8 & & \\
\hline 1733 & 39.0 & & \\
\hline 1734 & 36.0 & & \\
\hline 1735 & 33.9 & & \\
\hline 1736 & 34.5 & & \\
\hline 1737 & 36.7 & & \\
\hline 1738 & 37.6 & & \\
\hline 1739 & 36.3 & & \\
\hline 1740 & 32.3 & & \\
\hline 1741 & 32.1 & & \\
\hline
\end{tabular}

